EDUKACJA MIĘDZYKULTUROWA

2013, nr 2

ISSN 2299-4106

Ewa OgrodzKa-Mazur, Alina SzCZUREK-Boruta

\title{
Działalność naukowo-badawcza Zakładu Pedagogiki Ogólnej Uniwersytetu Śląskiego na Wydziale Etnologii i Nauk o Edukacji w latach 1989-2012. Wokół cieszyńskiej szkoły badań pogranicza ${ }^{1}$
}

Zakład Pedagogiki Ogólnej rozpoczął swoją działalność w strukturze Wydziału Pedagogiczno-Artystycznego cieszyńskiej filii Uniwersytetu Śląskiego jesienią 1989 roku. Powołany został z inicjatywy ówczesnego Prorektora ds. filii w Cieszynie - prof. zw. dr. hab. Wojciecha Kojsa, który funkcję kierownika Zakładu powierzył prof. zw. dr. hab. Tadeuszowi Lewowickiemu, związanemu z Uniwersytetem Warszawskim. Nawiązanie przez Profesora stałej współpracy z cieszyńską uczelnią było wyrazem zainteresowania problematyką pogranicza ze względu zarówno na usytuowanie ośrodka, prowadzone $\mathrm{w}$ nim dotychczas badania z zakresu pedagogiki kultury, jak i perspektywy podjęcia poczynań badawczych w obszarze pedagogiki międzykulturowej. Zamierzeniu temu towarzyszyła również troska Wydziału o rozwój młodej kadry naukowej.

Pierwsze działania Zakładu wiązały się z podjęciem współpracy z polskimi środowiskami oświatowymi, funkcjonującymi w czeskiej części południowego pogranicza - na Zaolziu - oraz przeprowadzeniem zespołowych badań diagnostycznych wśród uczniów uczęszczających do szkół podstawowych z polskim językiem nauczania. Plonem tych poczynań były opracowania - opatrzone

1 Tekst ten nawiązuje i poszerza opracowanie A. Szczurek-Boruty i E. Ogrodzkiej-Mazur: Działalność naukowo-badawcza, dydaktyczna i organizacyjna Zakładu i Katedry Pedagogiki Ogólnej Uniwersytetu Śląskiego na Wydziale Etnologii i Nauk o Edukacji w latach 1989-2012. Wokót cieszyńskiej szkoły badań pogranicza Profesora Tadeusza Lewowickiego. W: A. Szczurek-Boruta, E. Ogrodzka-Mazur (red.): Poza paradygmaty. Pedagogika międzykulturowa. T. 2. Księga pamiątkowa dedykowana Profesorowi Tadeuszowi Lewowickiemu. Cieszyn - Toruń 2012, Wydział Etnologii i Nauk o Edukacji Uniwersytetu Śląskiego, Wydawnictwo Adam Marszałek, s. 19-40. 
stałym logo autorstwa Lewowickiego - przedstawiające m.in. próbę diagnozy osobowości, hierarchie wartości i plany życiowe, a także uwarunkowania dróg życiowych dzieci i młodzieży z Zaolzia, społeczne funkcjonowanie młodzieży i problemy edukacji na pograniczu polsko-czechosłowackim, a później polsko-czeskim. Publikacje te zapoczątkowały wydawanie od 1992 roku serii Edukacja Międzykulturowa, która od roku 1996 jest przygotowywana przy współpracy Wyższej Szkoły Pedagogicznej Związku Nauczycielstwa Polskiego w Warszawie.

Fot. 1. Pracownicy Zakładu Pedagogiki Ogólnej

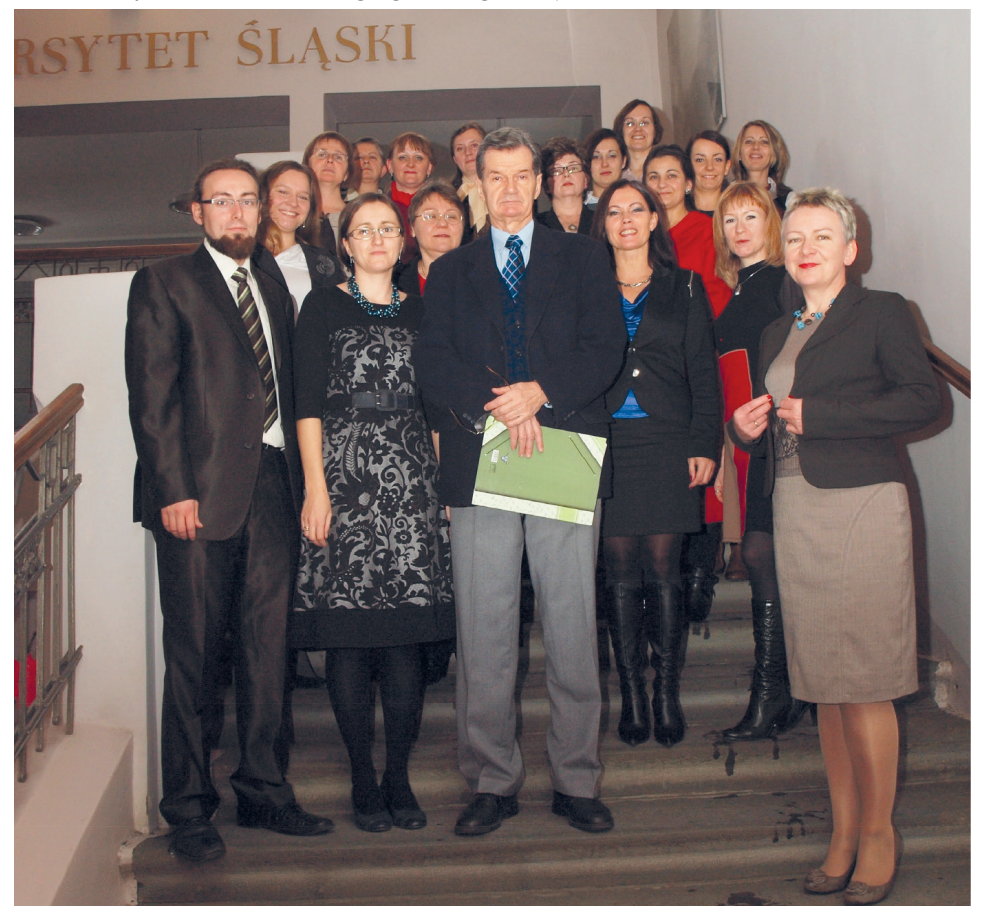

W I rzędzie od lewej: mgr Tomasz Gebel, dr Beata Kozieł, prof. zw. dr hab. Tadeusz Lewowicki, dr Barbara Grabowska

W II rzędzie od lewej: mgr Alicja Hruzd-Matuszczyk, dr Aniela Różańska, dr Jolanta Suchodolska, mgr Aleksandra Gancarz

W III rzędzie od lewej: dr hab. Ewa Ogrodzka-Mazur prof. UŚ, dr Urszula Klajmon-Lech, dr hab. Alina Szczurek-Boruta prof. UŚ, dr Gabriela Piechaczek-Ogierman

W IV rzędzie od lewej: dr Janina Urban, mgr Natalia Ruman, mgr Katarzyna Jas, mgr Katarzyna W. Czepiel

W V rzędzie od lewej: dr Barabara Chojnacka-Synaszko, dr Anna Gajdzica 
W pracach tych kategoria „pogranicza” - jak zauważa Lewowicki - traktowana była i jest nadal w bachtinowskim ujęciu - jako pogranicze kultur, społeczności, wyznań (a nie głównie - chociaż także - pogranicze państw i narodów). Dominującym wątkiem stały się zagadnienia najpierw edukacji wielokulturowej, a potem edukacji międzykulturowej. Uwagę badaczy współautorów kolejnych tomów - skupiały środowiska wychowawcze (rodzina, szkoła, społeczności lokalne, Kościoły różnych wyznań), problemy polityki społecznej i oświatowej, socjalizacji i kształtowania tożsamości, pracy nauczyciela w warunkach wielokulturowości, socjopatologii pogranicza, wykluczenia społecznego i edukacyjnego. Zagadnienia te były przedstawione w odczytaniach właściwych pedagogice, psychologii, socjologii, filozofii, językoznawstwu, teologii, kulturoznawstwu, historii (i innych dyscyplin szeroko pojmowanych nauk humanistycznych). Badaniom i studiom o charakterze metodologicznym towarzyszył namysł i próby ulepszania metodologii badań oraz sposobów interpretacji wyników badań. Tak powstało parę prac prezentujących teorie przydatne w badaniach międzykulturowych i modele takich badań ${ }^{2}$.

Szczególne znaczenia dla prowadzonych studiów i badań międzykulturowych ma opracowana przez Lewowickiego Teoria Zachowań Tożsamościowych $(\mathrm{TZT})^{3}$, stanowiąca nową perspektywę w poszukiwaniu prawidłowości warunkujących kształtowanie się poczucia tożsamości jednostek i grup

2 Por.: T. Lewowicki: Przedmowa. W: E. Ogrodzka-Mazur: Kompetencja aksjologiczna dzieci w młodszym wieku szkolnym. Studium porównawcze środowisk zróżnicowanych kulturowo. Katowice 2007, UŚ, s. 9; tenże: Przedmowa. W: A. Szczurek-Boruta: Zadania rozwojowe młodzieży i edukacyjne warunki ich wypetniania w środowiskach zróżnicowanych kulturowo i gospodarczo. Studium pedagogiczne. Katowice 2007, UŚ, s. 9.

3 Szersze omówienie koncepcji Teorii Zachowań Tożsamościowych można znaleźć w następujących opracowaniach T. Lewowickiego: Poczucie tożsamości narodowej mtodzieży - stałość i zmienność (uwagi końcowe). W: T. Lewowicki (red): Poczucie tożsamości narodowej młodzieży. Studium z pogranicza polsko-czeskiego. Cieszyn 1994, UŚ - Filia w Cieszynie, s. 127-135; Problemy tożsamości narodowej - w poszukiwaniu sposobów uogólnionych ujęć kwestii poczucia tożsamości i zachowań z tym poczuciem zwiazanych. W: M. M. Urlińska (red.): Edukacja a tożsamość etniczna. Toruń 1995, UMK, s. 51-63; O badaniach spoteczności pogranicza - od parcjalnych opisów ku elementom teorii zachowań tożsamościowych. W: J. Nikitorowicz (red.): Edukacja międzykulturowa - w kręgu potrzeb, oczekiwań i stereotypów. Białystok 1995, „Trans Humana", s. 13-26. 
w zmieniających się warunkach pogranicza (pograniczy). Teoria ta jest wykorzystywana do interpretacji wyników badań zespołowych i indywidualnych pracowników Zakładu, jak również przez innych badaczy zagadnień edukacji wielo- i międzykulturowej ${ }^{4}$.

W serii prac Edukacja Międzykulturowa, przygotowanych przez Zakład Pedagogiki Ogólnej, ukazało się dotychczas 50 tomów w $^{5}$ W rozprawach tych dostrzec można rozmaite ujęcia teoretyczne, odmienne podejścia metodologiczne, autorskie odczytania zjawisk i procesów zachodzących w środowiskach dzieci i młodzieży. Kolejne tomy serii wzbogacają i poszerzają dotychczasowy krąg poczynań badawczych o zagadnienia osobowościowego, aksjologicznego, społecznego, kulturowego funkcjonowania dzieci, młodzieży, dorosłych - studentów pedagogiki, nauczycieli, co stwarza możliwość prowadzenia wieloaspektowych oraz interdyscyplinarnych analiz porównawczych i ich interpretacji ${ }^{6}$.

W roku 2011 podjęto inicjatywę uruchomienia rocznika „Edukacja Międzykulturowa” wydawanego przez Zakład Pedagogiki Ogólnej Instytutu Nauk o Edukacji, Wydziału Etnologii i Nauk Edukacji Uniwersytetu Śląskiego w Katowicach. W 2012 roku ukazał się pierwszy numer czasopisma, które stanowi międzynarodowe forum naukowe, sprzyjające rozwijaniu nauk

4 Zob. publikacje wydane w serii Edukacja Międzykulturowa oraz następujące prace: J. Suchodolska: Edukacyjne, społeczno-kulturowe i gospodarcze uwarunkowania tożsamości młodzieży z pogranicza polsko-czeskiego. Opole 2003, UO (niepublikowana praca doktorska napisana pod kierunkiem naukowym prof. zw. dra hab. T. Lewowickiego); E. Ogrodzka-Mazur: Kompetencja aksjologiczna dzieci w młodszym wieku szkolnym. Studium porównawcze środowisk zróżnicowanych kulturowo. cyt. wyd.; A. Szczurek-Boruta: Zadania rozwojowe młodzieży i edukacyjne warunki ich wypetniania w środowiskach zróżnicowanych kulturowo i gospodarczo. Studium pedagogiczne. cyt. wyd.; M. Sobecki: Kultura symboliczna a tożsamość. Studium tożsamości kulturowej Polaków na Grodzieńszczyźnie z perspektywy edukacji międzykulturowej. Białystok 2007, „Trans Humana”; M. M. Urlińska: Szkoła polska na obczyźnie wobec dylematów tożsamościowych. Toruń 2007, UMK.

5 Wykaz wszystkich publikacji wydanych w serii prac Edukacja Międzykulturowa jest zamieszczony na końcu czasopisma w dziale Bibliografia.

6 Szerzej na ten temat pisze A Szczurek-Boruta w opracowaniu: Szkolnictwo wyższe a teoria, modele badań i praktyka edukacji międzykulturowej. W: T. Lewowicki, E. Ogrodzka-Mazur A. Szczurek-Boruta (red.): Edukacja międzykulturowa - dokonania, problemy, perspektywy. Cieszyn - Warszawa - Toruń 2011, Wydział Etnologii i Nauk o Edukacji Uniwersytetu Śląskiego, Wyższa Szkoła Pedagogiczna ZNP w Warszawie, Wydawnictwo Adam Marszałek, s. 153-203. 
pedagogicznych i upowszechnianiu pedagogiki międzykulturowej, umożliwiając tym samym przedstawicielom wielu specjalności pedagogicznych i reprezentantom innych dyscyplin - dzielenie się swymi osiągnięciami oraz nawiązanie współpracy i wymiany doświadczeń?

Obszarem szczególnych zainteresowań naukowych Zakładu są zagadnienia pogranicza oraz edukacji wielo-i międzykulturowej, podejmowane w zespołowych, interdyscyplinarnych badaniach naukowych pn. Społeczne, pedagogiczne $i$ kulturowe uwarunkowania rozwoju $i$ wychowania dzieci $i$ młodzieży na Pograniczu. W badaniach tych uczestniczyli i nadal uczestniczą - obok pracowników Zakładu - również członkowie innych ośrodków akademickich (m.in. z Białegostoku, Bydgoszczy, Gdańska, Krakowa, Opola, Poznania, Torunia, Warszawy, Zielonej Góry), skupieni w powołanej z inicjatywy Lewowickiego w 1994 roku - Federacji Społecznych Zespołów Badań Kultury i Oświaty Pogranicza, a od roku 2004 - w Zespole Pedagogiki Kultury i Edukacji Międzykulturowej pod patronatem Komitetu Nauk Pedagogicznych PAN.

Poszerzeniem działalności naukowej badaczy, reprezentantów różnych ośrodków naukowych w kraju, jest zainicjowanie przez Lewowickiego w 2007 roku powstania Stowarzyszenia Wspierania Edukacji Międzykulturowej. Jego celem jest rozwój polskiej myśli naukowej w dziedzinie pedagogiki międzykulturowej oraz realizacja badań naukowych i inicjatyw edukacyjnych mających związek z pedagogiką międzykulturową i edukacją w warunkach zróżnicowania kulturowego.

Poszerzeniem i uzupełnieniem naukowej działalności Zakładu są organizowane, przy współudziale Wyższej Szkoły Pedagogicznej ZNP w Warszawie, a od 2009 roku także Stowarzyszenia Wspierania Edukacji Międzykulturowej - cykliczne sympozja i konferencje poświęcone problematyce edukacji wielo- i międzykulturowej. Pierwsze tego typu spotkanie pt. Osobowość i plany życiowe dzieci z Zaolzia zorganizowano w 1993 roku w Czeskim Cieszynie wspólnie z Polskim Związkiem Kulturalno-Oświatowym. W latach 19932012 odbyło się łącznie 17 międzynarodowych konferencji naukowych. Dotyczyły one następujących kwestii:

1. Osobowość i plany życiowe dzieci z Zaolzia. Czeski Cieszyn, 15.01.1993.

2. Edukacja i problemy pogranicza. Ustroń - Cieszyn - Czeski Cieszyn, 18-19.09.1996.

7 E. Ogrodzka-Mazur: Wprowadzenie. „Edukacja Międzykulturowa” 2012, nr 1, s. 9-12. 
3. Edukacja międzykulturowa w Polsce i na świecie. Ustroń - Cieszyn, 12-14.10.1998.

4. Rodzina - Wychowanie - Wielokulturowość. Wisła, 12-13.10.1999.

5. Przemiany świadomości społecznej na pograniczach. Brenna, 17$-18.10 .2000$.

6. Kwestie wyznaniowe w społecznościach wielokulturowych (stereotypy, problemy edukacyjne, wspótczesne wyzwania społeczne). Ustroń-Jaszowiec, 23-24.10.2001.

7. Świat wartości i edukacja międzykulturowa. Ustroń-Jaszowiec, 24$-25.09 .2002$.

8. Język, komunikacja i edukacja w społecznościach wielokulturowych. Wisła, 21-22.10.2003.

9. Przemiany społeczno-cywilizacyjne a edukacja szkolna - problemy rozwoju indywidualnego i kształtowania się tożsamości. Ustroń, 11$-13.10 .2004$.

10. Polityka społeczna i oświatowa a edukacja międzykulturowa. Ustroń-Jaszowiec, 10-12.10.2005.

11. Edukacja międzykulturowa na Pograniczu w pierwszych latach rozszerzonej Unii Europejskiej. Wisła, 09-11.2006.

12. Socjalizacja i kształtowanie się tożsamości w warunkach wielokulturowości. Námestovo (Słowacja) - Cieszyn, 08-10.10.2007.

13. Socjopatologia pogranicza a edukacja. Cieszyn - Ustroń-Jaszowiec, 20-22.10.2008.

14. Społeczne, kulturowe i edukacyjne konteksty pedagogiki międzykulturowej. Cieszyn - Ustroń-Jaszowiec, 19-21.10. 2009.

15. Pedagogika międzykulturowa wobec wykluczenia społecznego i edukacyjnego, Cieszyn - Ustroń-Jaszowiec, 18-20.10.2010.

16. Edukacja międzykulturowa - dokonania, problemy, perspektywy, Cieszyn - Ustroń-Jaszowiec, 17-19.10. 2011.

17. Kultura w edukacji międzykulturowej, Cieszyn - Ustroń-Zawodzie, 24-26.09. 2012.

W ramach działalności naukowej Zakładu w latach 2003-2012 zrealizowano również sześć indywidualnych projektów badawczych, cztery projekty międzynarodowe (zespołowy i indywidualny), jeden w ramach Polsko-Litewskiego Funduszu Wymiany Młodzieży:

- Ocena opisowa w edukacji szkolnej - dr B. Chojnacka-Synaszko (projekt badawczy zakwalifikowany do finansowania przez KBN jako grant pro- 
motorski w latach 2004-2006 - zarejestrowany pod numerem $1 \mathrm{H} 01 \mathrm{~F}$ 074 26).

- Reforma oświaty a praktyka edukacji wczesnoszkolnej - dr A. Gajdzica (projekt badawczy zakwalifikowany do finansowania przez KBN jako grant promotorski w latach 2003-2004 - zarejestrowany pod numerem 2 H01F 016 24).

- Instytucjonalne formy opieki catkowitej nad dzieckiem upośledzonym umysłowo - analiza porównawcza regulacji prawnych $i$ rozwiazań praktycznych w Polsce $i$ w Czechach - dr M. Gil (projekt badawczy zakwalifikowany do finansowania przez KBN jako grant promotorski w latach 2004-2005 - zarejestrowany pod numerem 1H01F 06426).

- Działalność edukacyjna Kościoła katolickiego na Ślasku Cieszyńskim - dr U. Klajmon (projekt badawczy zakwalifikowany do finansowania przez KBN jako grant promotorski w roku 2004 - zarejestrowany pod numerem 1H01F 063 26).

- Nabywanie przez dziecko kompetencji aksjologicznej w sytuacji wielokulturowego pogranicza - dr hab. E. Ogrodzka-Mazur (projekt badawczy zakwalifikowany do finansowania przez KBN w latach 2002-2005 - zarejestrowany pod numerem 2 H01F 02022 ).

- Szkota i środowisko pozaszkolne w procesie ksztattowania postaw prozdrowotnych uczniów - dr G. Piechaczek-Ogierman (projekt badawczy zakwalifikowany do finansowania przez KBN jako grant promotorki w latach 2005-2007 - zarejestrowany pod numerem 1 H01F 017 28).

- Preparing Educators for Global Society (Grant FY 2003 Fulbright Educational Partnership. Program pomiędzy El Camino College i Uniwersytetem Śląskim - Filia w Cieszynie, realizowany w latach 2003-2006) - kierownik projektu: dr Janina Urban, uczestnicy: dr hab. E. Ogrodzka-Mazur, dr hab. A. Szczurek-Boruta.

- Grant Visegrad Fund pt. Slovakian language in minority milieu, realizowany w latach 2007-2008 - dr J. Urban - pracownik grupy przedstawicieli partnerów współpracujących (UŚ Katowice, UK w Pradze, VJÚ v Bratysławie) z głównym organizatorem grantu Výskumný ústav Slovákov v Mad'ársku.

- Grant International Visegrad Fund pt. Teaching native language and bilingual com-munity of the Slovaks in Serbia, Hungary, Romania, Poland, Czech Republic, realizowany w roku 2008 - dr J. Urban - koordynator współpracy z Republiki Czeskiej (Asociation of Slovak peda- 
gogues on the Province level, Bacsky Petrovec, Rep. Serbia; Research Institute of the Slovaks in Hungary, Békéscsaba, Hungaria; Asociation for the education and the consulting in Nadlac, Romania).

- Grant Kolorowe Ścieżki Euroregionu. Doskonalenie zawodowe nauczycieli w zakresie edukacji regionalnej i międzykulturowej. Numer rejestracyjny: CZ.3.22/2.3.00/09.01504, realizowany w latach 2010-2011 w ramach Programu Operacyjnego Współpracy Transgranicznej CR-RP. Uniwersytet Śląski w Katowicach występuje w projekcie jako partner Centrum Pedagogicznego dla Polskiego Szkolnictwa Narodowościowego w Czeskim Cieszynie (CR). Koordynator projektu - dr Anna Gajdzica; osoby uczestniczące: dr hab. prof. UŚ Alina Szczurek-Boruta, dr Barbara Grabowska, dr Aniela Różańska.

- Trudne rozmowy o Czesławie Miłoszu - tolerancja, dialog, partnerska wspótpraca. Projekt realizowany wraz ze studentami i pracownikami naukowymi Wileńskiego Uniwersytetu Pedagogicznego, finansowany przez Polsko-Litewski Fundusz Wymiany Młodzieży, nr projektu: FPL1-065-2011; mgr A. Gancarz - udział w projekcie.

- Projekt habilitacyjny pt. Poczucie tożsamości młodzieży i jego uwarunkowania (studium polskiej mniejszości narodowej na Zaolziu w perspektywie porównawczej), zakwalifikowany do finansowania w latach 2010-2012 przez MNiSW - zarejestrowany pod numerem N N106 324339. Umowa nr 3243/B/H03/2010/39. Kierownik projektu - dr B. Grabowska. Aktualnie trwa realizacja: jednego grantu habilitacyjnego finansowanego przez MNiSW oraz dwóch projektów badawczych własnych finansowanych przez Narodowe Centrum Nauki:

- Projekt habilitacyjny pt. Mniejszości narodowe krajów Grupy Wyszehradzkiej w procesach integracyjnych Europy - tożsamość młodzieży mniejszości autochtonicznych, zakwalifikowany do finansowania w latach 2009-2013 przez MNiSW. Kierownik projektu - dr J. Urban.

- Zespołowy projekt badawczy pt. Edukacja dzieci w polskich szkołach na obczyźnie: strategie kulturalizacyjne - poczucie tożsamości - dystans kulturowy, zakwalifikowany do finansowania w latach 2011-2014 przez Narodowe Centrum Nauki - zarejestrowany pod numerem N N106 428740. Umowa nr 4287/B/H03/2011/40. Kierownik projektu - dr hab. prof. UŚ E. Ogrodzka-Mazur; osoby uczestniczące: dr A. Gajdzica, mgr A. Hruzd-Matuszczyk, dr U. Klajmon-Lech, dr G. Piechaczek-Ogierman, dr A. Różańska. 
- Projekt badawczy własny pt. Uczyć się od innych i uczyć - nauczać innych - praca nauczyciela $w$ warunkach wielokulturowości, zakwalifikowany do finansowania w latach 2011-2014 przez Narodowe Centrum Nauki - zarejestrowany pod numerem N N106 416640. Umowa nr 4166/B/H03/2011/40. Kierownik projektu - dr hab. prof. UŚ A. Szczurek-Boruta.

Działalność naukowo-badawcza pracowników Zakładu Pedagogiki Ogólnej nie ogranicza się tylko do pogranicza polsko-czeskiego. Od samego początku istnienia Zakładu jego członkowie uczestniczą w wyjazdowych seminariach naukowych, konferencjach w kraju i za granicą. Odbywają staże naukowe: El Camino College, Torrance USA, w ramach Programu Unii Europejskiej Socrates/Erasmus: Uniwersytet Ostrawski (Czechy), Uniwersytet Mateja Bela w Bańskiej Bystrzycy (Słowacja), Uniwersytet św. Cyryla i Metodego w Trnawie (Słowacja), Kirchlichen Pädagogischen Hochschule der Diözese Graz-Seckau (Austria), Uniwersytet Katolicki w Lille (Francja), Instytut Kształcenia Pedagogicznego w Cambrai-Lille (Francja).

Problematyka wielokulturowości oraz edukacji międzykulturowej promowana jest przez pracowników Zakładu w cyklicznych wykładach dla studentów studiów podyplomowych Zintegrowana Edukacja Wczesnoszkolna $i$ Wychowanie Przedszkolne (od 2002 roku), studiów podyplomowych dla nauczycieli w zakresie ICT, języków obcych i nauczania przedmiotu Wychowanie do życia $w$ rodzinie oraz Terapia Pedagogiczna (2007-2008); dla studentów Uniwersytetu Trzeciego Wieku (od roku 2004); dla studentów i pracowników El Camino College w Los Angeles - California, USA (2004-2009) - realizowanych również z wykorzystaniem stałych kontaktów online w ramach przedmiotu Komunikacja w spotecznościach wielokulturowych i eksperymentalnego projektu badawczego Global Education Through Technology (GETT); dla studentów i pracowników Uniwersytetu Ostrawskiego w Czechach (od 2006 roku) oraz Centre de Formation Pedagogique w Cambrai Francja (2004) w ramach Programów Unii Europejskiej Socrates/Erasmus. Zajs muje również wiodące miejsce w tematyce prac magisterskich i licencjackich, przygotowywanych pod kierunkiem naukowym pracowników Zakładu.

Ważne znaczenie dla rozwoju warsztatu naukowo-badawczego - oprócz badań zespołowych - ma udział wszystkich członków Zakładu w comiesięcznych seminariach naukowych prowadzonych od 23 lat przez Profesora Lewowickiego, poświęconych m.in. prezentowaniu indywidualnych projektów badawczych, metodologii badań pedagogicznych, w tym orientacjom teo- 
retycznym i obszarom działalności edukacyjnej, jak również teoriom i modelom przydatnym w badaniach międzykulturowych. Pod opieką naukową Profesora powstały 2 rozprawy habilitacyjne (3 kolejne zostaną opublikowane w tym roku) oraz 11 prac doktorskich nawiązujących do problematyki edukacji wielo-i międzykulturowej. Dzięki tym stałym spotkaniom seminaryjnym wytworzył się również szczególny rodzaj więzi między członkami zespołu, będący swoistym poczuciem tożsamości i zarazem pewnej odrębności i niepowtarzalności, kształtowanej kulturą intelektualną Profesora ${ }^{8}$.

Halina Rusek stwierdza, iż „można mówić o istnieniu w Cieszynie oryginalnej, mocno osiadłej w strukturze Wydziału Etnologii i Nauk o Edukacji, szkoły teorii i badań pogranicza. Twórcą jej jest Profesor Tadeusz Lewowicki, który dwadzieścia lat temu rozpoczął współpracę z ośrodkiem akademickim w Cieszynie i [...] należy do grona osób, które przez swoją działalność naukowo-badawczą i dydaktyczną znacząco wpłynęły na profil naukowy i dydaktyczny tego wydziału, szczególnie w zakresie pedagogiki. [...] Prowadzona przez Profesora Lewowickiego cieszyńska szkoła badaczy pogranicza zajmuje wśród podobnych szkół tworzonych od kilkunastu lat w różnych polskich uczelniach należną jej wysoką pozycję. Znana jest także poza granicami Polski. Jest formą pracy naukowo-badawczej, którą Uniwersytet Śląski może się szczycić 9 . Podobną opinię wyraża Andrzej Radziewicz-Winnicki, podkreślając, że „Profesor Tadeusz Lewowicki jest od dawna już twórcą szkoły naukowej w obszarze edukacji międzykulturowej. [...] Wraz z szeroką rzeszą współpracowników konsekwentnie wskazuje na założenia i idee edukacji międzykulturowej. Przedstawia nowe zadania edukacyjne w społeczeństwie pluralistycznym, strategie edukacji i kierunki polityki edukacyjnej w wybra-

nych krajach oraz szkolnictwo lokalnej mniejszości i podstawy prawne jego funkcjonowania. W obrębie funkcjonowania szkoły przyjęto, że najwłaściwszym podejściem edukacji międzykulturowej będzie stosowanie wielowa-

8 E. Ogrodzka-Mazur: Autorytet uczonego a kreowanie środowiska pedagogów międzykulturowych. W: A. Szczurek-Boruta, E. Ogrodzka-Mazur (red.): Poza paradygmaty. Pedagogika międzykulturowa. T. 2. Księga pamiatkowa dedykowana Profesorowi Tadeuszowi Lewowickiemu. cyt. wyd., s. 64-90.

9 H. Rusek: Cieszyńska szkoła badań pogranicza. W: T. Lewowicki, E. Ogrodzka-Mazur, J. Urban (red.): Społeczne uwarunkowania edukacji międzykulturowej. T. 1. Konteksty teoretyczne. Cieszyn - Warszawa -Toruń 2009, Wydział Etnologii i Nauk o Edukacji Uniwersytetu Śląskiego, Wyższa Szkoła Pedagogiczna ZNP w Warszawie, Wydawnictwo Adam Marszałek, s. 18-20. 
riantowych rozwiązań edukacyjnych, na które największy wpływ winny mieć społeczności lokalne i one to, w zależności od potrzeb i aspiracji grup mniejszościowych, określają i będą promować satysfakcjonujące ich rozwiązania ${ }^{10}$.

Zakład Pedagogiki Ogólnej inicjuje także działania w zakresie praktyki edukacyjnej, obejmujące:

- Wprowadzenie do programu studiów od 2002 roku - na kierunku pedagogika - przedmiotu edukacja wielo- $i$ międzykulturowa (obecnie podstawy edukacji wielo- i międzykulturowej - (studia pierwszego stopnia), edukacja wielo- i międzykulturowa z metodyką (studia drugiego stopnia) oraz przedmiotów: kwestie wyznaniowe w społecznościach wielokulturowych, komunikacja codzienna w edukacji, socjalizacja i wychowanie w społecznościach wielokulturowych; edukacja szkolna w społecznościach wielokulturowych (studia pierwszego stopnia); społeczno-kulturowe konteksty edukacji, projektowanie działań edukacyjnych kreujących jednostki (studia drugiego stopnia).

- Powołanie w 2004 roku studenckiego Koła Naukowego Edukacji Międzykulturowej, którego działalność przyczynia się do aktywizacji środowiska akademickiego Wydziału Etnologii i Nauk o Edukacji w Cieszynie. Członkowie Koła uczestniczą w pracach badawczych Zakładu Pedagogiki Ogólnej, propagują kwestie edukacji międzykulturowej wśród studentów, dzieci i młodzieży w swoich środowiskach lokalnych, podejmują działania edukacyjne (terapeutyczne i interwencyjne) na rzecz nadania rangi Innemu i wsparcia jednostki w nabywaniu tożsamości własnej i społecznej. Wymiernymi efektami pracy Koła są: teksty naukowe studentów publikowane w kraju i za granicą; organizowane konferencje naukowe (łącznie od 2005 roku odbyło się 18 cyklicznych konferencji na temat Poznajmy Innego, połączonych z war-

10 A. Radziewicz-Winnicki: Opinia o catoksztatcie dorobku naukowego oraz działalności prof. zw. dr. hab. Tadeusza Lewowickiego, w zwiazku z wnioskiem Rady Wydziatu Historyczno-Pedagogicznego oraz Senatu Uniwersytetu Opolskiego o nadanie Panu Profesorowi Tadeuszowi Lewowickiemu godności Doktora Honoris Causa. W: Tadeusz Lewowicki. Doktor Honoris Causa Universitatis Opoliensis. Opole 2004, UO, s. 30-31; tenże: Idea postępu w czasie społecznym Katedry Pedagogiki Ogólnej Wydziału Etnologii i Nauk o Edukacji Uniwersytetu Ślaskiego w ośrodku akademickim w Cieszynie. W: T. Lewowicki, E. Ogrodzka-Mazur, J. Urban (red.): Spoteczne uwarunkowania edukacji międzykulturowej. T.1. Konteksty teoretyczne. Cieszyn - Warszawa -Toruń 2009, Wydział Etnologii i Nauk o Edukacji Uniwersytetu Śląskiego, Wyższa Szkoła Pedagogiczna ZNP w Warszawie, Wydawnictwo Adam Marszałek, s. 35-42. 
sztatami dla dzieci, młodzieży i studentów); współpraca ze studenckimi kołami naukowymi innych ośrodków akademickich, stowarzyszeniami, placówkami oświatowymi w kraju i za granicą, m.in. z El Camino College w Torrance California USA (od 2005 roku), z Uniwersytetem Ostrawskim (od 2006 roku), Centrum Pedagogicznym dla Polskiego Szkolnictwa Narodowościowego w Republice Czeskiej (od roku 2006). Ważnym osiągnięciem studentów działających w Kole jest otrzymanie stypendiów ministra nauki i szkolnictwa wyższego za osiągnięcia w nauce, działalność organizacyjną i naukową (od 2005 roku stypendia uzyskało 8 studentek, członkiń Koła).

Dalsze poczynania Zakładu będą się koncentrować na zespołowych badaniach naukowych, dotyczących społecznych, pedagogicznych i kulturowych uwarunkowań rozwoju i wychowania dzieci i młodzieży z Pogranicza, kwestii przemian społeczno-cywilizacyjnych, edukacji szkolnej, problemów kształtowania się tożsamości, teorii i modeli badań międzykulturowych, a także przygotowania nauczycieli i pedagogów do pracy w społecznościach wielokulturowych oraz realizowania europejskiego wymiaru edukacji wielo- i międzykulturowej.

Działalność badawcza Zakładu Pedagogiki Ogólnej dostarcza różnych narzędzi do interpretacji faktów, kontekstów, a także przemian kulturowych we współczesnym świecie. Stanowi ważną inspirację zarówno dla badań naukowych, jak i praktycznych działań edukacyjnych, przygotowujących młode pokolenia do życia w wielokulturowym świecie, pozwala poznać warunki sprzyjające tym działaniom i je utrudniające.

\section{Bibliografia}

Lewowicki T.: Poczucie tożsamości narodowej młodzieży - stałość i zmienność (uwagi końcowe). W: T. Lewowicki (red): Poczucie tożsamości narodowej młodzieży. Studium z pogranicza polsko-czeskiego. Cieszyn 1994, UŚ - Filia w Cieszynie.

Lewowicki T.: O badaniach społeczności pogranicza - od parcjalnych opisów ku elementom teorii zachowań tożsamościowych. W: J. Nikitorowicz (red.): Edukacja międzykulturowa - w kręgu potrzeb, oczekiwań i stereotypów. Białystok 1995, „Trans Humana”. 
Lewowicki T.: Problemy tożsamości narodowej - w poszukiwaniu sposobów uogólnionych ujęć kwestii poczucia tożsamości i zachowań z tym poczuciem zwiazanych. W: M. M. Urlińska (red.): Edukacja a tożsamość etniczna. Toruń 1995, UMK.

Lewowicki T.: Kształcenie uniwersyteckie - siła tradycji, presja wspótczesności, pytania o przyszłość, przesłania. W: W. Ambrozik, K. Przyszczypkowski (red.): Uniwersytet. Społeczeństwo. Edukacja. Poznań 2004, UAM.

Lewowicki T.: Przedmowa. W: A. Szczurek-Boruta: Zadania rozwojowe mtodzieży i edukacyjne warunki ich wypetniania $w$ środowiskach zróżnicowanych kulturowo i gospodarczo. Studium pedagogiczne. Katowice 2007, UŚ. Lewowicki T.: Przedmowa. W: E. Ogrodzka-Mazur: Kompetencja aksjologiczna dzieci w młodszym wieku szkolnym. Studium porównawcze środowisk zróżnicowanych kulturowo. Katowice 2007, UŚ.

Ogrodzka-Mazur E.: Kompetencja aksjologiczna dzieci w młodszym wieku szkolnym. Studium porównawcze środowisk zróżnicowanych kulturowo. Katowice 2007, UŚ.

Ogrodzka-Mazur E.: Wprowadzenie. „Edukacja Międzykulturowa” 2012, nr 1, s. 9-12.

Ogrodzka-Mazur E.: Autorytet uczonego a kreowanie środowiska pedagogów międzykulturowych. W: A. Szczurek-Boruta, E. Ogrodzka-Mazur (red.): Poza paradygmaty. Pedagogika międzykulturowa. T. 2. Ksiegga pamiatkowa dedykowana Profesorowi Tadeuszowi Lewowickiemu. Cieszyn - Toruń 2012, Wydział Etnologii i Nauk o Edukacji Uniwersytetu Śląskiego, Wydawnictwo Adam Marszałek.

Radziewicz-Winnicki A.: Opinia o całoksztatcie dorobku naukowego oraz działalności prof. zw. dr. hab. Tadeusza Lewowickiego, w zwiazku z wnioskiem Rady Wydziatu Historyczno-Pedagogicznego oraz Senatu Uniwersytetu Opolskiego o nadanie Panu Profesorowi Tadeuszowi Lewowickiemu godności Doktora Honoris Causa. W: Tadeusz Lewowicki. Doktor Honoris Causa Universitatis Opoliensis. Opole 2004, UO.

Radziewicz-Winnicki A.: Idea postępu w czasie społecznym Katedry Pedagogiki Ogólnej Wydziału Etnologii i Nauk o Edukacji Uniwersytetu Śląskiego w ośrodku akademickim w Cieszynie. W: T. Lewowicki, E. Ogrodzka-Mazur, J. Urban (red.): Spoteczne uwarunkowania edukacji międzykulturowej. T.1. Konteksty teoretyczne. Cieszyn - Warszawa -Toruń 2009, Wydział Etnologii i Nauk o Edukacji Uniwersytetu Śląskiego, Wyższa Szkoła Pedagogiczna ZNP w Warszawie, Wydawnictwo Adam Marszałek. 
Rusek H.: Cieszyńska szkoła badań pogranicza. W: T. Lewowicki, E. Ogrodzka-Mazur, J. Urban (red.): Spoteczne uwarunkowania edukacji międzykulturowej. T. 1. Konteksty teoretyczne. Cieszyn - Warszawa -Toruń 2009, Wydział Etnologii i Nauk o Edukacji Uniwersytetu Śląskiego, Wyższa Szkoła Pedagogiczna ZNP w Warszawie, Wydawnictwo Adam Marszałek. Sobecki M.: Kultura symboliczna a tożsamość. Studium tożsamości kulturowej Polaków na Grodzieńszczyźnie z perspektywy edukacji międzykulturowej. Białystok 2007, „Trans Humana”.

Suchodolska J.: Edukacyjne, społeczno-kulturowe i gospodarcze uwarunkowania tożsamości młodzieży z pogranicza polsko-czeskiego. Opole 2003, UO (niepublikowana praca doktorska napisana pod kierunkiem naukowym prof. zw. dra hab. T. Lewowickiego).

Szczurek-Boruta A.: Zadania rozwojowe młodzieży i edukacyjne warunki ich wypetniania w środowiskach zróżnicowanych kulturowo i gospodarczo. Studium pedagogiczne. Katowice 2007, UŚ.

Szczurek-Boruta A.: Szkolnictwo wyższe a teoria, modele badań i praktyka edukacji międzykulturowej. W: T. Lewowicki, E. Ogrodzka-Mazur A. Szczurek-Boruta (red.) Edukacja międzykulturowa - dokonania, problemy, perspektywy. Cieszyn - Warszawa - Toruń 2011, Wydział Etnologii i Nauk o Edukacji Uniwersytetu Śląskiego, Wyższa Szkoła Pedagogiczna ZNP w Warszawie, Wydawnictwo Adam Marszałek.

Szczurek-Boruta A., Ogrodzka-Mazur E.: Działalność naukowo-badawcza, dydaktyczna i organizacyjna Zakładu i Katedry Pedagogiki Ogólnej Uniwersytetu Ślaskiego na Wydziale Etnologii i Nauk o Edukacji w latach 1989-2012. Wokót cieszyńskiej szkoty badań pogranicza Profesora Tadeusza Lewowickiego. W: A. Szczurek-Boruta, E. Ogrodzka-Mazur (red.): Poza paradygmaty. Pedagogika międzykulturowa. T. 2. Księga pamiątkowa dedykowana Profesorowi Tadeuszowi Lewowickiemu. Cieszyn - Toruń 2012, Wydział Etnologii i Nauk o Edukacji Uniwersytetu Śląskiego, Wydawnictwo Adam Marszałek.

Urlińska M. M.: Szkoła polska na obczyźnie wobec dylematów tożsamościowych. Torun 2007, UMK. 